\title{
ТЕОРЕТИЧНІ ОСНОВИ ПЛАНУВАННЯ НАВЧАЛЬНОЇ РОБОТИ З ФІЗИЧНОЇ КУЛЬТУРИ В ШКОЛІ
}

\author{
Кандидат педагогічних наук, доцент О.М. Худолій; \\ старший викладач А.В. Забора
}

\section{Харківський державний педагогічний університет ім. Г.С. Сковороди}

В основі планування і організації навчального процесу лежить програмно-цільовий підхід, у відповідності з яким визначається цільове завдання і субзавдання різного рангу.

Проходження навчального матеріалу планується у відповідності до схеми: якщо (умова) ... то (дія) ... .

Наприклад:

1. ЯКЩО учні 9-го класу в упорі можуть виконати 5 згинань-розгинань рук за 3,5-4,5 сек, ТО можливо навчання підйому махом вперед, IHАКШЕ спеціально організований процес розвитку сили.

2. ЯКЩО учні правильно виконують упор на руках, ТО можливо навчання розмахуванню в упоpi на руках, IHAKШЕ навчання упору на руках.

3. ЯКЩО учні правильно виконують розмахування в упорі на руках, ТО виконати розмахування $з$ різною амплітудою, ІНАКШЕ продовжити навчання розмахуванню.

4. ЯКЩО учні уміють виконувати розмахування з різною амплітудою, ТО навчання вправам, що підводять до виконання вправи в цілому.

5. ЯКЩО учні освоїли вправи, що підводять, ТО навчання виконувати вправі в цілому.

6. ЯКЩО учні уміють виконувати підйом махом вперед, ТО виконати вправу в зв'язці.

Спеціально проведені дослідження дозволили сформулювати принципові установки до планування навчальної роботи з гімнастики в школі. Принципові установки - це самостійна категорія методичних положень і правил, приватних по відношенню до загальних принципів фізичного виховання і спортивного тренування. Вони, по-перше, розвивають керівні ідеї, укладені в цих принципах застосовно до сучасних умов, i, по-друге, виступають в якості конкретних правил програмування навчального процесу.

\section{Установка на визначення субзавдань навчання цільовій руховій дії}

В рамках навчання вирішуються задачі розвитку рухового хисту, підвищення рівня спеціальнорухової підготовленості для засвоєння конкретних вправ. Практично це реалізується в послідовному розмішенні навчальних завдань на певному часовому відрізку. Рішення задач і підбір навчальних завдань виконуються в наступному порядку:

- розвиток рухових здібностей;

- навчання вихідним і кінцевим положенням вправи;
- навчання діям, без яких неможливо виконати вправу, що вивчається;

- навчання вмінням управляти рухами;

- навчання вправам, що підводять;

- навчання вправі в з’єднанні.

\section{Установка на попередній розвиток рухових здібностей}

Послідовність, порядок розвитку рухового хисту визначаються, по-перше, біологічними закономірностями розвитку організму i, nо-друге, метою підготовки. Аналіз стану перспективи розвитку тренованості і визначення достатності їх для досягнення мети підготовки - це основа технології розвитку рухових здібностей учнів.

Не секрет, що зростання сили зв'язане з фізіологічним поперечником м'язу, морфо-функціональними перебудовами на рівні ЦНС. Але є другий шлях підвищення сили - це мобілізація більшого числа мотонейронів і вдосконалення міжм'язової координації.

Якщо для виконання силової вправи достатньо сили $X+s$, де $X-$ середнє арифметичне, $s-$ стандартне відхилення, що характеризує вагання сили на 2-3 заняттях, то підвищення силових здібностей може проходити за рахунок вдосконалення міжм'язової координації, інакше - необхідні структурні перетворення на рівні м'язової і центрально-нервової систем. В першому випадку це досягається точним підбором рухових завдань, відповідних змагальній вправі. В другому випадку - оптимальним дозуванням силових навантажень на тривалому етапі підготовки.

Наприклад:

Для утримання «упору руки в сторони» на кільцях сила повинна бути рівна $87 \%$ від ваги тіла (дані Ю.В. Менхіна, А.В. Плоткіна). Якщо спортсмен важить 60 кг, то сила груп м'язів, що приводять, повинна бути рівна 52,2 кГ. Якщо спортсмен показує результат $50 \pm 4$ кГ $(X \pm s)$, то підвищення силових здібностей досягається за рахунок вдосконалення міжм'язової координації.

Розглянемо другий випадок розвитку силових здібностей. Для створення передумов для морфофункціональних перебудов необхідні фізичні навантаження. Якщо фізичне навантаження викликає виснаження енергетичних ресурсів організму (порушення гомеостазу), то відбувається надлишкове відновлення і переведення організму на новий, більш високий рівень функціонування (М.М. Яков- 
лєв, 1953, 1958, 1971; С.П. Летунов, 1966; Л.С. Евгеньєва та ін., 1975; А.А. Вipy, 1977, 1980; А.Н. Воробьов, 1977).

Під впливом фізичних навантажень в клітках багатьох фізіологічних систем виникає одне і те ж зрушення - дефіцит багатих енергією фосфорних сполучень та збільшення потенціалу фосфоріліровання. В свою чергу це викликає активізацію генетичного апарату кліток, посилюючи синтез нуклеїнових кислот і білків. В результаті збільшується потужність системи мітохондрій, зростає вироблення аденозінтрифосфорної кислоти (АТФ) на одиницю маси тканини і дефіцит АТФ усувається (Ф.З. Меєрсон, 1973; В.П. Скарбніков, 1980; Ю.В. Верхошанський, 1985).

Фізичні навантаження в такому випадку повинні застосовуватися так довго, як це дозволяе період поновлення білка в м'язах спортсмена. За даними Ю.В. Верхошанського (1988) строк півперіоду життя білків м'язів, тобто час, за який вони наполовину оновлюють склад, - біля 30 діб. А.В. Волков (1970) стверджує, що періодичні зміни величини максимальної мускульної сили гімнастів залежать від характеру і рівня обмінних процесів, тривалість таких процесів вкладається в період, рівний 13,2 $\pm 1,7$ дня.

Можна припустити, що за певних умов, на протязі місяця занять фізичною культурою, можливі морфо-функціональні зрушення позитивного спрямування в м'язовій і центрально-нервовій системах. Розглянемо ці умови.

При розвитку сили локальної групи м'язів слід оптимізувати навантаження і враховувати: 1) стан ЦНС; 2) скорочувальні здібності м’язів; 3) рівень енергетичного потенціалу спортсменів.

Оптимізація навантажень включає: 1) визначення величини, на яку може збільшитися сила групи м'язів; 2) визначення впливу, що неминуче призведе до зросту сили; 3) визначення тривалості такого впливу.

Центральна нервова система зберігає високий функціональний стан за умови, якщо силова робота виконується в першій половині заняття. Скорочувальні здібності м'язів підвищуються, якщо ЦНС не знаходиться в стадії втоми, підібраний оптимальний вплив і поперечник м'язу має тенденцію до збільшення.

Аналіз наведеного вище матеріалу дозволив припустити, що енергетичний потенціал має тенденцію до збільшення, якшо:

1) виконується силова робота в різних режимах;

2) силова робота поєднується з об'ємною роботою в одному занятті.

В результаті дослідження встановлено, що:

1) ефективним для розвитку максимальної сили $€$ комбінований метод;

2) швидкісно-силова робота повинна проводитися безпосередньо після підвищення максимальної сили.

\section{Методика планування навчальної роботи з фізичної культури (на прикладі гімнастики)}

Технологія навчального процесу з гімнастики полягає в послідовному проходженні програмного матеріалу. Порушення технології навчального процесу веде до непослідовності в вивченні гімнастичних вправ, що подовжує час навчання. Однак програма обмежується лише переліком рухових завдань, не визначаючи порядок і тривалість вивчення різноманітних вправ.

Існує безліч варіантів вивчення одного і того ж навчального матеріалу з гімнастики. В зв'язку з цим завжди стоїть проблема вибору з цієї безлічі оптимального варіанта. Завдання значно ускладнюється трудомісткістю гімнастики, великою кількістю вправ, обмеженістю часу на їх засвоєння, недостатнім рівнем фізичної і технічної підготовленості учнів. Подолати об'єктивні труднощі за допомогою традиційного планування, основаного на практичному досвіді викладача, не завжди вдається. Реальну допомогу може надати графічний опис навчального процесу, що дасть можливість застосування математичних методів (моделей) для його планування.

Одним з таких методів є система мережевого планування і управління (СПУ), що дозволить представити навчальний матеріал 3 гімнастики у вигляді графіка з наступним нескладним математичним розрахунком.

Суттєвістю мережевого моделювання є зображення комплексу робіт, що планується у вигляді графічної схеми, яка складається з заданих точок, з'єднаних лініями. Основні логічні елементи мережевого графіка - це роботи та події. Під дійсною роботою в гімнастиці слід розуміти будь-яку рухову дію, що вимагає витрат часу і ресурсів. До поняття «робота» відноситься і чекання - пасивний процес, що не вимагає витрат праці, фізичних зусиль, але займає час. Окрім робіт дійсних, що вимагають витрат часу і сил, існують фіктивні роботи (залежності). Фіктивна робота - це логічний зв'язок між елементами, що не вимагає витрат часу і фізичної праці, але яка вказує, що можливість початку однієї роботи безпосередньо залежить від результатів іншої. Подія - підсумок зробленої роботи, проміжний або остаточний результат одного або декількох рухових завдань, що дозволить розпочати виконання наступних елементів мережевого графіка. Дійсні роботи та чекання на мережевому графку зображають суцільними стрілками; фіктивні - пунктирними; події - кружками, прямокутниками, квадратами або іншими геометричними фігурами з порядковими номерами. Будь-яка послідовність робіт мережевого графіка, в якому кінцева подія однієї роботи співпадає з початковою подією наступної за нею, називається шляхом. Повний шлях з'єднує вихід- 
ну подію 3 завершальною. Найбільш тривалий з всіх повних шляхів даної мережі називається критичним (позначається жирними стрілками), (B.B. Трупан, 1980).

На рис. 1 наведений масштабний сітьовий графік навчання гімнастичних вправ учнів 9-х класів. Графік побудований на основі першої і другої принципових установок і дасть більш ясне уявлення про порядок навчання гімнастичних вправ шкільної програми.
Робота 0-1 погоджується з найбільш складним рухом і направлена в нашому випадку на розвиток сили розгинача передпліччя. Засоби підбираються так, щоб вони мали структурну схожість з рухами, що вивчаються, і наближалися до них за характером м'язових зусиль. Для підвищення сили на 30-40\% (подія 1) використовується комбінований метод розвитку сили, другий варіант. Силова робота організується на чотирьох послідовних станціях: I станція - метод динамічних зу-

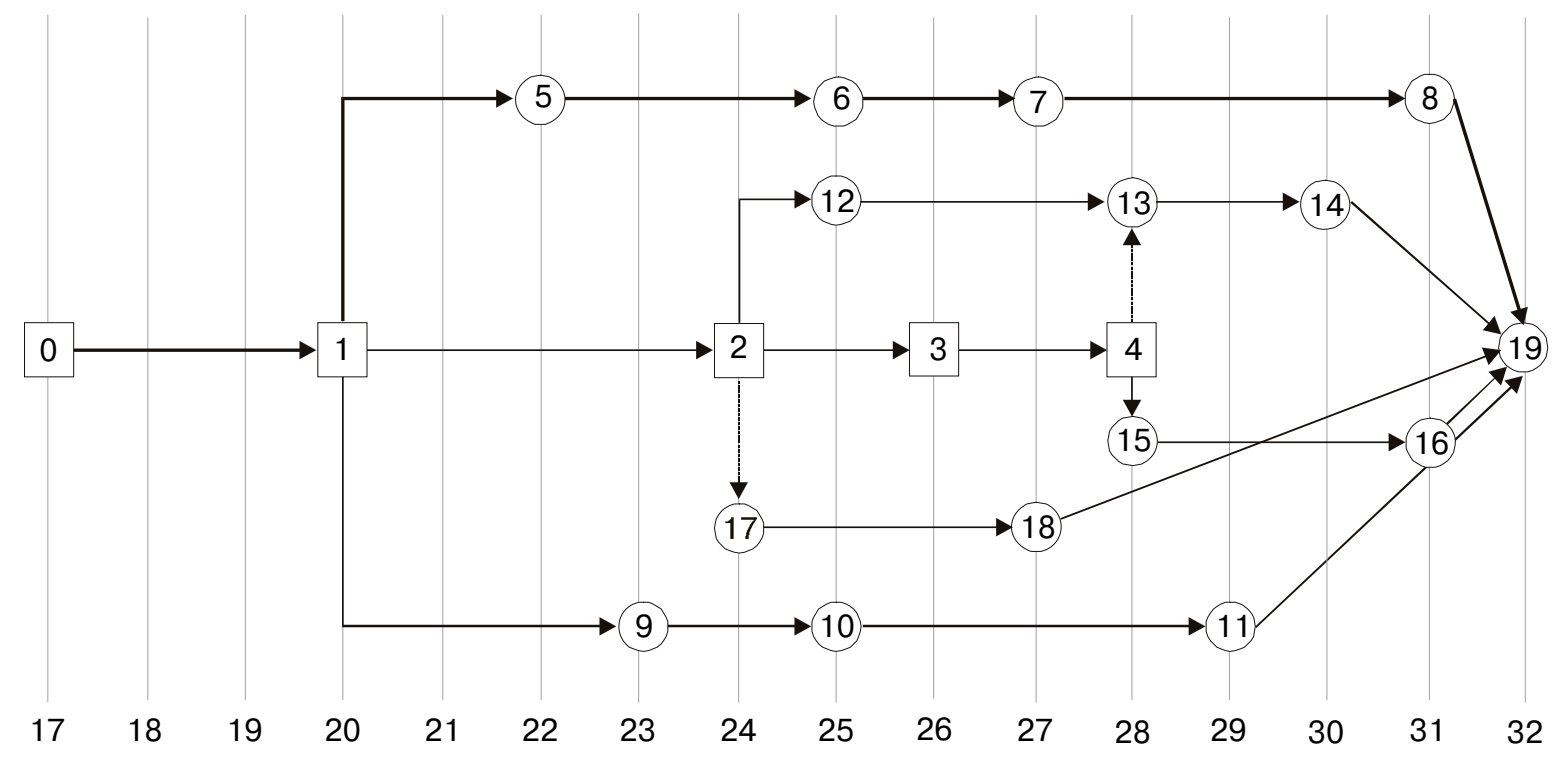

Рис. 1. Масштабний сітьовий графік навчання гімнастичних вправ учнів 9-х класів (див. табл. 3)

Ключовим моментом в побудові мережевого графіка є визначення найбільш складної вправи, ланки, навколо якої зв'язуються всі вправи. Таким рухом для школярів 9-х класів може бути підйом махом вперед в упор на паралельних бруcax. Цей рух складний за координацією і вимагає прояву максимальних зусиль за короткий час.

Відповідно до другої установки рухова підготовленість повинна передувати навчанню рухам, тому першою виконується робота, яка спрямована на розвиток сили розгиначів передпліччя. Присвоїмо цій роботі шифр $0-1$ і занесемо в таблицю вихідної інформації такі дані:

\section{0-1 Розвиток сили м'язів плечового поясу. 4 уроки} Комбінований метод, II варіант.

На масштабному сітьовому графіку відкладемо пряму і позначимо подію прямокутником 1 :

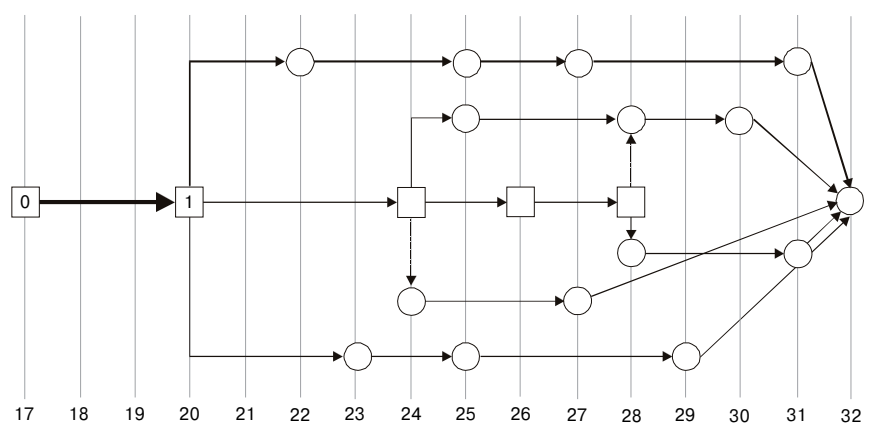

силь, II станція - метод максимальних зусиль, III станція - метод ізометричних зусиль, IV станція - метод повторних зусиль.

Спеціально проведені дослідження показали ефективність такого підходу. Так, після двох тижнів занять у школярів 9-х класів збільшилася сила розгиначів передпліччя на 30-50\% (О.М. Худолій, О.В. Іващенко, 1996; О.М. Худолій, А.В. Забора, 2000). Робота 0-1 продовжується 4 заняття. Заняття повністю спрямовані на розвиток сили.

Наступні роботи спрямовані на розвиток сили м'язів «спини», «рук і тулуба». Присвоїмо цій роботі шифр 1-2, в таблицю вихідної інформації впишемо:

0-1 Розвиток сили м'язів «спини», «рук 4 уроки і тулуба». Комбінований метод, І варіант.

На масштабному сітьовому графіку з точки 1 відкладемо пряму і позначимо подію 2:

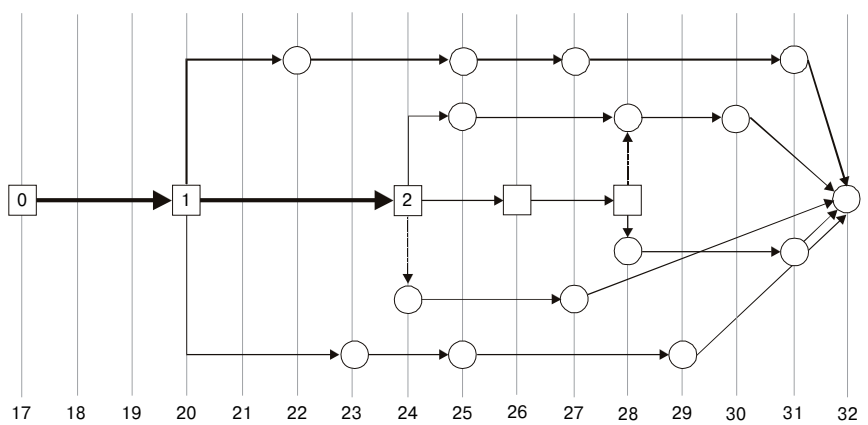


Робота 1-2 є базовою для навчання стійці силою на голові і руках, підйому переворотом в упор. Засоби підбираються з урахуванням особливостей навчання вищезгаданим вправам. Силова робота організується на двох станціях. Тривалість роботи на кожній станції 4-6 хв. Перша станція - вправи для розвитку м'язів спини. Учні виконують перше завдання $з$ максимальною швидкістю, друге завдання - 3 максимальними зусиллями, третє - 3 ізометричними зусиллями, четверте -3 повторними зусиллями. Вправи першої станції поєднуються з навчанням стійці силою на голові і руках. Друга станція - вправи для рук і тулуба. Всі вправи направлені на створення умов для навчання підйому переворотом силою. Підсумком роботи $1-2 €$ достатній рівень силової підготовленості для виконання названих вправ (24 заняття).

Паралельно з роботою 1-2 продовжуємо навчання підйому махом вперед. В таблицю вихідної інформації впишемо шифр роботи $1-5$, іiї назву, кількість уроків:

\section{0-1 Навчання вихідним і кінцевим поло- женням; рухи без яких неможливо виконання вправ.}

2 уроки

На масштабному сітьовому графіку відкладемо відрізок 1-5:

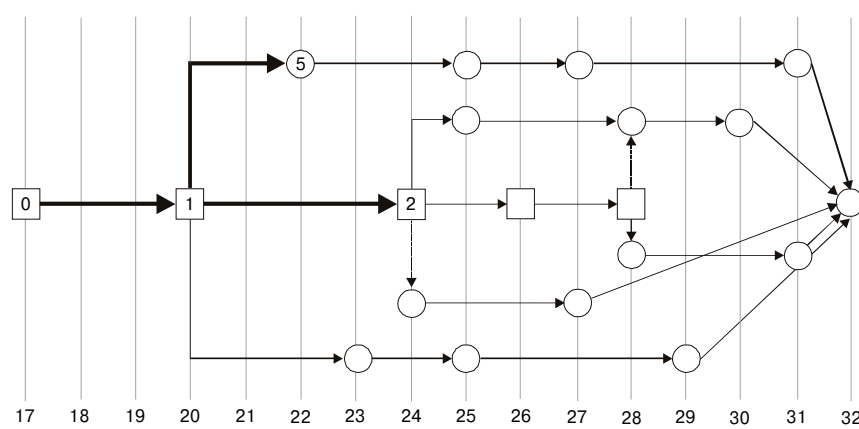

Робота 1-5 зв'язана з II та III серією навчальних завдань навчання підйому махом вперед. Тривалість роботи 2 заняття.

3 точки 1 починається робота, спрямована на навчання умінню виконувати кувирки вперед з різною швидкістю. Позначимо цю роботу як 1-9 і занесемо в таблицю наступну інформацію:

\section{1-9 Навчання умінню виконувати кувирки 2 уроки} вперед з різною швидкістю.

На масштабному сітьовому графіку відкладемо відрізок, який відповідає роботі 1-9:

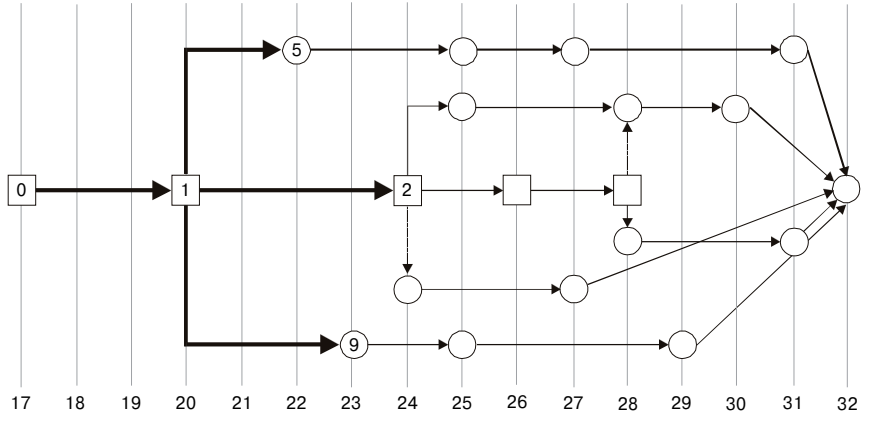

Отже роботи $\mathbf{1 - 2}, \mathbf{1}-\mathbf{5}, \mathbf{1 - 9}$ виконуються паралельно. Так як вони належать до різних структурних груп, то негативного перенесення навику не повинно спостерігатися.

По досягненні події 2 переходимо до робіт 2-12 і 2-17. Аналогічно вищенаведеному в таблицю вихідної інформації вносимо шифр цих робіт і назву, а також відкладаємо відрізки на графіку (табл. 1, рис. 1). Робота 2-12 зв'язана з II серією навчальних завдань навчання стійці силою на голові, а робота 2-17 - фіктивна робота, яка вказує, що можливість початку роботи безпосередньо залежить від результатів роботи $1-2$.

Після досягнення події 2 продовжуємо роботу з розвитку сили (робота $2-3)$. Силова підготовка організується на двох станціях. Перша станція вправи для м'язів рук, спини і ніг, що направлені на створення готовності до виконання стрибка зігнувши ноги. Друга станція - вправи для м'язів рук і тулуба, що створюють умови для відмінного виконання підйому переворотом силою.

Робота 3-4 продовжує вирішувати завдання силової підготовленості, зв'язані з ефективним виконанням стрибка зігнувши ноги і підйому переворотом силою. Роботи 17-18 та 18-19 спрямовані на оволодіння підйомом силою в упор на перекладині.

Роботи 5-6, 6-7, 7-8, 8-19 спрямовані на оволодіння підйомом махом вперед і містять засоби навчання умінням управляти рухами, підводящі вправи та вправу в цілому. Ці роботи складають найбільш тривалий шлях сіті:

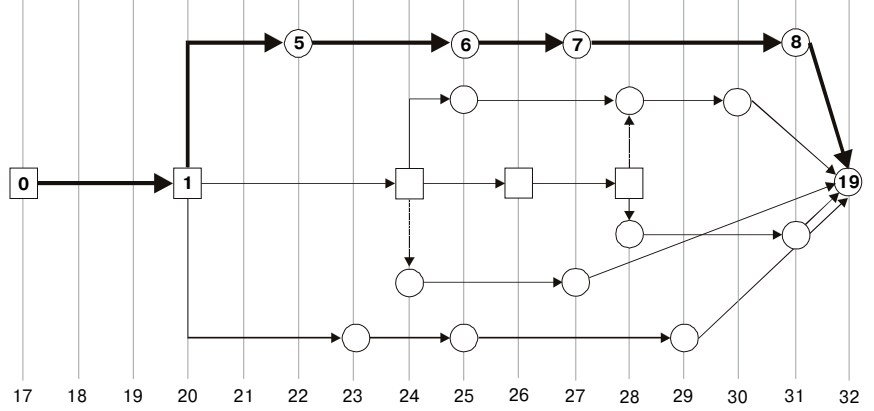

Робота 5-6 триває 4 заняття, робота 6-7 2 заняття, робота 7-8 - 4 заняття. При навчанні вправ використовується метод алгоритмічних розпоряджень, який як, відомо, дає гарні результати при оволодінні вправами шкільної гімнастики (А.М. Шлемін).

Таким чином, сітьовий графік проходження навчального матеріалу будується на основі фізичної готовності і порядку навчання найбільш складному руху і дає можливість уникнути по можливості напластування складного матеріалу в одному занятті (див. рис. 1, табл. 1).

На основі сітьового графіка формулюються завдання навчання (табл. 2), будується тематичний план-графік (табл. 3) та упорядковуються конспекти уроків. 
Таблиця 1

Таблиця вихідної інформації

\begin{tabular}{|c|c|c|c|}
\hline Шифр & Робота & $\begin{array}{l}\text { Попередня } \\
\text { робота }\end{array}$ & Кількість уроків \\
\hline & Розвиток сили групи м'язів & & \\
\hline $0-1$ & $\begin{array}{l}\text { Розвиток сили м'язів плечового поясу. Комбінований метод, } \\
\text { II варіант }\end{array}$ & - & $4(17,18,19,20)$ \\
\hline $1-2$ & $\begin{array}{l}\text { Розвиток сили м'язів «спини», «рук і тулуба». Комбінований } \\
\text { метод, І варіант }\end{array}$ & $0-1$ & $4(21,22,23,24)$ \\
\hline $2-3$ & $\begin{array}{l}\text { Розвиток сили м'язів «рук, спини і ніг», «рук і тулуба». } \\
\text { Комбінований метод, І варіант }\end{array}$ & $0-1,1-2$ & $2(25,26)$ \\
\hline $3-4$ & $\begin{array}{l}\text { Розвиток сили м'язів «рук, спини і ніг». Комбінований метод, } \\
\text { І варіант }\end{array}$ & $0-1,1-2,2-3$ & $2(27,28)$ \\
\hline & Підйом махом вперед & & \\
\hline $1-5$ & $\begin{array}{l}\text { Навчання вихідним і кінцевим положенням; рухів, без яких } \\
\text { неможливо виконання вправи }\end{array}$ & $0-1$ & $2(21,22)$ \\
\hline $5-6$ & Навчання умінням управляти рухами & $0-1,1-5$ & $4(22,23,24,25)$ \\
\hline $6-7$ & Навчання вправам, які підводять & $0-1,1-5,5-6$ & $2(26,27)$ \\
\hline $7-8$ & Навчання вправі в цілому, в зв'язці & $\begin{array}{l}0-1,1-5,5-6 \\
6-7\end{array}$ & $4(28,29,30,31)$ \\
\hline $8-19$ & Виконання елемента в комбінації & $\begin{array}{l}0-1,1-5,5-6 \\
6-7\end{array}$ & $2(31,32)$ \\
\hline & Довгий кувирок вперед з трьох кроків & & \\
\hline $1-9$ & $\begin{array}{l}\text { Навчання умінню виконувати кувирки вперед з різною } \\
\text { швидкістю }\end{array}$ & $0-1$ & $3(21,22,23)$ \\
\hline $9-10$ & Вправи, які підводять & $1-9$ & $3(23,24,25)$ \\
\hline $10-11$ & Вправа в цілому & $9-10$ & $5(25,26,27,28,29)$ \\
\hline $11-19$ & $\begin{array}{l}\text { Виконання елемента в комбінації } \\
\text { Стійка силою на голові і руках }\end{array}$ & $0-1,1-9,9-10$ & $4(29,30,31,32)$ \\
\hline $2-12$ & $\begin{array}{l}\text { Навчання вихідним і кінцевим положенням (2 серія навчаль- } \\
\text { них завдань) }\end{array}$ & $1-2$ & $2(24,25)$ \\
\hline $12-13$ & Навчання підводящим вправам (5 серія навчальних завдань) & $1-2,2-12$ & $3(26,27,28)$ \\
\hline $4-13$ & $\begin{array}{l}\text { Фіктивна робота, яка вказує на залежність ефективності вико- } \\
\text { нання стійки силою від силової підготовленості м'язів спи- } \\
\text { ни і рук }\end{array}$ & $1-2,2-3,3-4$ & \\
\hline $13-14$ & Виконання вправи в цілому & $\begin{array}{l}1-2,2-12 \\
12-13,14-13\end{array}$ & $3(28,29,30)$ \\
\hline $14-19$ & Виконання вправи в комбінації & $\begin{array}{l}1-2,2-12 \\
2-13,13-14\end{array}$ & $3(30,31,32)$ \\
\hline & Підйом переворотом силою в упор на перекладині & & \\
\hline $2-17$ & $\begin{array}{l}\text { Фіктивна робота, яка вказує, що початок роботи залежить } \\
\text { від результатів роботи }\end{array}$ & $1-2$ & \\
\hline $17-18$ & Виконання вправи в цілому & $1-2,2-17$ & $(25,26,27)$ \\
\hline $18-19$ & Виконання вправи в комбінації & $\begin{array}{l}1-2,2-17 \\
17-18\end{array}$ & $5(28,29,30,31,32)$ \\
\hline $4-15$ & $\begin{array}{l}\text { Стрибок зігнувши ноги через козла в довжину, } h=115 \text { см } \\
\text { Фіктивна робота, яка вказує на залежність навчання від швид- } \\
\text { кісно-силової підготовки учнів }\end{array}$ & $1-2,2-3,3-4$ & \\
\hline $15-16$ & Виконання опорного стрибка в цілому & $4-15$ & $4(28,29,30,31)$ \\
\hline $16-19$ & Виконання стрибка в умовах, наближених до змагань & $4-15,16-19$ & $2(31,32)$ \\
\hline
\end{tabular}




\section{Завдання уроку фізичної культури}

Узагальнена мета занять гімнастикою в школі - розвиток, освіта, виховання школярів. Від поставлених завдань уроку залежить підбір рухових завдань. В різних методичних рекомендаціях стверджується, що в уроці повинно бути три завдання, які тісно зв'язані з узагальненою метою. Це вірно, але кількість завдань залежить від можливості дроблення навчального матеріалу, від логічного зв'язку окремих уроків. Сітьовий графік розподілення навчального матеріалу дозволяє поставити коректні завдання до кожного уроку, уникнути надмірного дроблення матеріалу, а також виникнення ситуації негативного переносу рухового навику. Важливе значення при формулюванні завдань уроку має також і підбір методів розвитку рухових здібностей і навчання. Використання комбінованого методу розвитку сили, методу алгоритмічних розпоряджень для навчання вправ дозволяє конкретизувати задачі уроку, зробити їх доступними для реалізації. Сформулюємо завдання і запишемо їх в таблицю.

\begin{tabular}{|l|l|}
\multicolumn{1}{c|}{ № } \\
\multicolumn{1}{c|}{ Навчальні завдання }
\end{tabular}

Продовження табл. 2

\begin{tabular}{|l|l|}
\hline № п/п & \multicolumn{1}{|c|}{ Завдання уроку } \\
\hline & Дівчата: \\
& 1. Повторити акробатичні вправи. \\
& 2. Повторити опорний стрибок боком. \\
& 3. Навчити вису прогнувшись на н/ж, \\
& з опорою стопами об в/ж і переходу \\
& в упор на н/ж. \\
\hline 23 & Юнаки: \\
& 1. Сприяти розвитку спеціальної рухової \\
& підготовленості учнів для виконання: \\
& а) стійки силою на голові і руках; \\
& б) підйому переворотом силою. \\
& 2. Навчити підйому махом вперед: четверта
\end{tabular}

2. Навчити підйому махом вперед: четверта серія навчальних завдань.

3. Навчити довгому кувирку вперед з трьох кроків: підводящі вправи.

4. Навчити стрибку зігнувши ноги через козла: третя серія навчальних завдань.

Дівчата:

1. Повторити акробатичні вправи.

2. Повторити опорний стрибок боком.

3. Повторити вправи на р/в брусах.

\begin{tabular}{l|l}
24 & Юнаки: \\
& 1. Навчити підйому переворотом в упор
\end{tabular} силою.

2. Навчити підйому махом вперед: четверта серія навчальних завдань.

3. Навчити стійці силою на голові і руках: друга серія навчальних завдань.

4. Навчити довгому кувирку вперед з трьох кроків: підводящі вправи.

5. Навчити стрибку зігнувши ноги через козла: третя серія навчальних завдань.

Дівчата:

Ті самі задачі, що на 23 уроці.

25 Юнаки

1. Навчити підйому переворотом в упор силою.

2. Навчити підйому махом вперед: четверта серія навчальних завдань.

3. Навчити стійці силою на голові і руках: підводящі вправи.

4. Навчити довгому кувирку вперед з трьох кроків.

5. Навчити стрибку зігнувши ноги через козла: третя серія навчальних завдань.

Дівчата:

Ті самі задачі, що на 24 уроці.

26 Юнаки:

1. Навчити підйому переворотом в упор силою.

2. Навчити підйому махом вперед: п'ята серія навчальних завдань.

3. Навчити стійці силою на голові і руках: підводящі вправи.

4. Навчити довгому кувирку вперед з трьох кроків.

5. Навчити стрибку зігнувши ноги через козла: третя серія навчальних завдань.

Дівчата:

Ті самі задачі, що на 25 уроці.

27 Юнаки:

1. Навчити підйому махом вперед: підводящі вправи. 
Продовження табл. 2

\begin{tabular}{|c|c|}
\hline № $\pi / \Pi$ & Завдання уроку \\
\hline & $\begin{array}{l}\text { 2. Навчити стійці силою на голові і руках: } \\
\text { п’ята серія навчальних завдань. } \\
\text { 3. Навчити стрибку зігнувши ноги через } \\
\text { козла: третя серія навчальних завдань. } \\
\text { 4. Повторити раніше вивчені вправи. } \\
\text { Дівчата: } \\
\text { Ті самі задачі, що на } 26 \text { уроці. }\end{array}$ \\
\hline 28 & $\begin{array}{l}\text { Юнаки: } \\
\text { 1. Навчити стійці силою на голові. } \\
\text { Далі ті ж задачі, що на } 27 \text { уроці. } \\
\text { Дівчата: } \\
\text { Ті самі задачі, що на } 27 \text { уроці. }\end{array}$ \\
\hline 29 & $\begin{array}{l}\text { Юнаки: } \\
\text { 1. Навчити підйому махом вперед. } \\
\text { 2. Навчити стійці силою на голові і руках. } \\
\text { 3. Навчити стрибку зігнувши ноги: п'ята } \\
\text { серія навчальних завдань } \\
\text { 4. Повторити раніше вивчені вправи. } \\
\text { Дівчата: } \\
\text { 1. Повторити раніше вивчені вправи. }\end{array}$ \\
\hline 30 & $\begin{array}{l}\text { Юнаки: } \\
\text { 1. Навчити підйому махом вперед. } \\
\text { 2. Навчити стрибку зігнувши ноги: п'ята } \\
\quad \text { серія навчальних завдань. } \\
\text { 3. Повторити раніше вивчені вправи. } \\
\text { Дівчата: } \\
\text { 1. Повторити раніше вивчені вправи. }\end{array}$ \\
\hline $31-32$ & $\begin{array}{l}\text { 1. Виконати на оцінку контрольні вправи } \\
\text { і навчальні комбінації. }\end{array}$ \\
\hline
\end{tabular}

\section{Тематичний план-графік та конспекти} уроку

Деталізуємо зміст сітьового графіка проходження навчального матеріалу і визначимо засоби для вирішення завдань уроку. Для цього складемо тематичний план-графік (див. табл. 3).

Тематичний план-графік конкретизує навчальний план і програму. Він визначає:

1) зміст навчального матеріалу;

2) послідовність навчання вправ;

3) взаємозв'язок уроків фізичної культури;

4) систему контрольних уроків.

В тематичний план-графік внесемо всі вправи, які вивчаються в дев'ятому класі. Для кожної вправи складемо навчальну програму типу алгоритмічних розпоряджень. Під кожною вправою запишемо серії навчальних завдань. Вправи розташуємо за порядком складності. На основі сітьового графіка визначимо порядок і строки виконання серій навчальних завдань. Вправи серій навчальних завдань підбираються так, щоб учні могли їх засвоїти на одному уроці. Напроти вправи в графі номера уроку позначаємо навчання («н»), якщо вправу виконуємо перший раз, або повторення («П»), якщо вправа виконувалася на попередньому уроці. Для розвитку сили окремих груп м'язів використаємо засоби, які рекомендуються програмою, а також перші серії навчальних завдань вправ, які вивчаються.
Міцність рухового навику в гімнастиці визначається можливістю виконання вивченої вправи в зв'язці, в комбінації. В тематичному плані передбачимо, після оволодіння програмним матеріалом, виконання комбінацій на кожному снаряді. Останні два уроки присвячуємо контролю за оволодінням програмним матеріалом. Для цього заплануємо виконання комбінацій і навчальних нормативів і відповідно, в графах номера уроків поставимо позначку контролю («К»).

План-конспект уроку найбільш повно розкриває зміст, методику та організацію кожного заняття. Конспект уроку містить завдання уроку, тривалість його частин, чергування видів, їх зміст та дозування. Вправи підготовчої частини підбираються згідно змісту основної частини. При складанні конспекту уроку враховуються результати попередніх уроків і вносяться відповідні корективи.

Конспект уроку складається на підставі тематичного плану-графіка з врахуванням наступних загальних вимог:

1. Кожний конспект уроку складається 3 3-х частин: зміст, де вказуються фізичні вправи, розподілені за частинами уроку; дозування фізичних вправ і організаційно-методичні примітки.

2. Конспект уроку складається в відповідності 3 планом на чверть і повинен мати чіткі педагогічні завдання.

3. Запис вправ робиться докладно і термінологічно правильно.

4. Всі вправи дозуються.

5. Вправи основної частини уроку при необхідності записуються окремо для хлопчиків і дівчат.

6. До окремих частин уроку даються чіткі організаційно-методичні примітки. Необхідно, щоб методичні примітки показували шляхи рішення завдань уроку.

7. Вправи слід записувати в точній методичній послідовності.

Вимоги до підготовчої частини уроку:

1. При запису підготовчих вправ спочатку показується вихідне положення, після цього за розділеннями записується вправа.

2. В графі «дозування» проти кожної вправи вказується час, кількість повторень або дистанція в метрах.

3. В організаційно-методичних примітках записують: темп, характеристики бігу або ходьби, зауваження про головні частини вправи.

Вимоги до основної частини уроку:

1. Вправи основної частини уроку записуються в послідовності розучування або вдосконалення.

2. В графі «дозування» проти кожної вправи вказується кількість підходів, кількість повторень в підході і інтервал відпочинку між підходами.

3. В організаційно-методичних примітках можуть бути записані примітки з організації уроку, методики навчання та виховання. 
Тематичний план-графік проходження навчального матеріалу з гімнастики для учнів 9-х класів

\begin{tabular}{|c|c|c|c|c|c|c|c|c|c|c|c|c|c|c|c|c|c|}
\hline \multirow{2}{*}{ № } & \multirow{2}{*}{ Зміст } & \multicolumn{16}{|c|}{ Номери уроків } \\
\hline & & 17 & 18 & 19 & 20 & 21 & 22 & 23 & 24 & 25 & 26 & 27 & 28 & 29 & 30 & 31 & 32 \\
\hline $\begin{array}{l}1 \\
2\end{array}$ & $\begin{array}{l}\text { Основи знань } \\
\text { Стройові вправи: } \\
\text { а) перестроювання в русі; } \\
\text { б) рух до точок залу; } \\
\text { в) рухи протиходом, «змійкою» }\end{array}$ & $\begin{array}{l}+ \\
n \\
\Pi \\
\Pi\end{array}$ & $\begin{array}{l}+ \\
\Pi \\
\Pi \\
\Pi\end{array}$ & $\begin{array}{l}+ \\
\\
\Pi \\
\Pi \\
\Pi\end{array}$ & $\begin{array}{l}\Pi \\
\Pi \\
\Pi\end{array}$ & $\begin{array}{l}n \\
\pi \\
\pi\end{array}$ & $\begin{array}{l}\Pi \\
\Pi \\
\Pi\end{array}$ & $\begin{array}{l}+ \\
\Pi \\
\Pi \\
\Pi\end{array}$ & $\begin{array}{l}+ \\
\Pi \\
\Pi \\
\Pi\end{array}$ & $\begin{array}{l}\Pi \\
\Pi \\
\Pi\end{array}$ & $\begin{array}{l}+ \\
\Pi \\
\Pi \\
\Pi\end{array}$ & $\begin{array}{l}\Pi \\
\Pi \\
\Pi\end{array}$ & $\begin{array}{l}\Pi \\
\Pi \\
\Pi\end{array}$ & $\begin{array}{l}+ \\
n \\
n \\
\pi\end{array}$ & $\begin{array}{l}\Pi \\
\Pi \\
\Pi\end{array}$ & $\begin{array}{l}+ \\
\Pi \\
\Pi \\
\Pi\end{array}$ & $\begin{array}{l}\Pi \\
\Pi \\
\Pi\end{array}$ \\
\hline 3 & $\begin{array}{l}\text { Загальнорозвиваючі вправи: } \\
\text { а) в русі (№ } 1,2 \text {;); } \\
\text { б) на місці (№ 3); } \\
\text { в) в парах (№ 4) }\end{array}$ & $\mathrm{H}$ & $\begin{array}{l}\text { ח } \\
\text { п }\end{array}$ & $\begin{array}{l}\Pi \\
\Pi\end{array}$ & $\begin{array}{l}\text { п } \\
\text { п }\end{array}$ & $\begin{array}{l}\Pi \\
\mathrm{H}\end{array}$ & $\begin{array}{l}\Pi \\
\Pi\end{array}$ & $\begin{array}{l}\Pi \\
\Pi\end{array}$ & $\begin{array}{l}\Pi \\
\Pi\end{array}$ & $\begin{array}{l}\mathrm{H} \\
\Pi\end{array}$ & $\begin{array}{l}\Pi \\
\Pi\end{array}$ & $\begin{array}{l}\Pi \\
\Pi\end{array}$ & $\begin{array}{l}\Pi \\
\Pi\end{array}$ & $\begin{array}{l}\Pi \\
\Pi\end{array}$ & $\begin{array}{l}\Pi \\
\Pi\end{array}$ & $\begin{array}{l}\Pi \\
\text { п }\end{array}$ & $\begin{array}{l}\Pi \\
\Pi\end{array}$ \\
\hline $\begin{array}{l} \\
- \\
- \\
- \\
-\end{array}$ & $\begin{array}{l}\text { Виси і упори: } \\
\text { Юнаки } \\
\text { Перекладина: } \\
\text { з вису підйом переворотом в упор силою } \\
\text { з вису на зігнутих руках вис прогнувшись; } \\
\text { з положення лежачи на перекладині упор; } \\
\text { підйом переворотом в упор з допомогою; } \\
\text { підйом переворотом в упор самостійно; } \\
\text { навчальна комбінація }\end{array}$ & & & & & $\begin{array}{l}+ \\
\mathrm{H} \\
\mathrm{H}\end{array}$ & $\begin{array}{l}+ \\
\Pi \\
\Pi \\
H\end{array}$ & $\begin{array}{l}+ \\
\Pi \\
\Pi \\
\mathrm{H}\end{array}$ & $\begin{array}{l}+ \\
\Pi \\
\Pi \\
\mathrm{H}\end{array}$ & $\begin{array}{l}+ \\
\Pi \\
\Pi\end{array}$ & $\begin{array}{l}+ \\
\Pi \\
\Pi \\
H\end{array}$ & + & п & П & П & $\mathrm{K}$ & K \\
\hline $\begin{array}{l}- \\
- \\
- \\
- \\
- \\
- \\
- \\
- \\
- \\
- \\
-\end{array}$ & $\begin{array}{l}\text { Бруси: } \\
\text { з упору на руках підйом махом вперед } \\
\text { розмахування в упорі; } \\
\text { упор на руках з провисанням; } \\
\text { розмахування в упорі на руках; } \\
\text { розмахування в упорі на руках по заданій } \\
\text { амплітуді; } \\
\text { розмахування в упорі на руках з мінімаль- } \\
\text { ним збільшенням маху вперед; } \\
\text { розмахування в упорі на руках з підльотом } \\
\text { і мінімальним збільшенням маху вперед; } \\
\text { з упору на зігнутих руках підйом махом } \\
\text { вперед; } \\
\text { з упору на передпліччях підйом махом } \\
\text { вперед; } \\
\text { на похилих брусах підйом махом вперед } \\
\text { в сід ноги нарізно; } \\
\text { підйом махом вперед з допомогою; } \\
\text { підйом махом вперед самостійно; } \\
\text { підйом махом вперед і зіскок махом назад. } \\
\text { Навчальна комбінація }\end{array}$ & & & & & $\begin{array}{l}+ \\
\Pi \\
\Pi \\
\Pi\end{array}$ & $\begin{array}{l}+ \\
\Pi \\
\Pi \\
\Pi\end{array}$ & $\begin{array}{l}+ \\
\Pi \\
\Pi \\
\Pi \\
\text { ח } \\
\text { H }\end{array}$ & $\begin{array}{l}+ \\
\Pi \\
\Pi\end{array}$ & $\begin{array}{l}+ \\
\Pi \\
\Pi\end{array}$ & $\begin{array}{l}+ \\
\Pi \\
\Pi\end{array}$ & $\begin{array}{l}+ \\
\Pi \\
\Pi\end{array}$ & $\begin{array}{l}+ \\
\Pi \\
\Pi\end{array}$ & 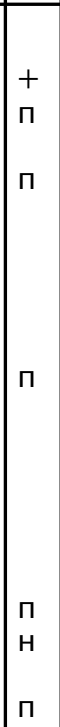 & 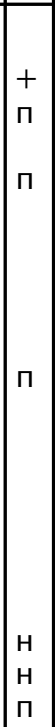 & $\begin{array}{l} \\
\\
\\
\\
\\
\text { K } \\
\text { H } \\
\text { K }\end{array}$ & K \\
\hline $\begin{array}{l}- \\
- \\
-\end{array}$ & $\begin{array}{l}\text { Дівчата } \\
\text { Різновисокі бруси: } \\
\text { вис прогнувшись на н/ж, спираючись } \\
\text { стопами об в/ж, перехід в упор на н/ж; } \\
\text { махом однією і поштовхом другою, підйом } \\
\text { переворотом в упор на н/ж; } \\
\text { зіскок з сіду на стегні. } \\
\text { Навчальна комбінація }\end{array}$ & & & & & $\begin{array}{l}\Pi \\
\mathrm{H}\end{array}$ & $\begin{array}{l}\Pi \\
\Pi\end{array}$ & $\begin{array}{l}\Pi \\
\Pi\end{array}$ & $\begin{array}{l}\Pi \\
\Pi\end{array}$ & $\begin{array}{l}\Pi \\
\Pi\end{array}$ & $\begin{array}{l}\Pi \\
\Pi\end{array}$ & $\begin{array}{l}\Pi \\
\Pi \\
\Pi\end{array}$ & $\begin{array}{l}\Pi \\
\Pi \\
\Pi\end{array}$ & $\begin{array}{l}\Pi \\
\\
\Pi \\
\Pi \\
\Pi\end{array}$ & \begin{tabular}{|l|}
$\pi$ \\
$\pi$ \\
$\pi$
\end{tabular} & $\begin{array}{l}\text { П } \\
\text { К } \\
\text { К } \\
\text { K }\end{array}$ & K \\
\hline $\begin{array}{l}- \\
- \\
- \\
- \\
- \\
- \\
- \\
- \\
- \\
-\end{array}$ & $\begin{array}{l}\text { Вправи в рівновазі } \\
\text { на підлозі: } \\
\text { підскоки на одній нозі; } \\
\text { напівприсід; } \\
\text { сід кутом; } \\
\text { поворот в присіді; } \\
\text { зіскок з напівприсіда; } \\
\text { на лаві: } \\
\text { підскоки на одній нозі; } \\
\text { напівприсід; } \\
\text { сід кутом; } \\
\text { поворот в присіді; } \\
\text { зіскок з напівприсіда; } \\
\text { вправи на колоді: } \\
\text { підскоки на одній нозі; }\end{array}$ & $\begin{array}{l}+ \\
+ \\
+ \\
+ \\
+ \\
+\end{array}$ & $\begin{array}{l}+ \\
+ \\
+ \\
+ \\
+ \\
+ \\
+ \\
+ \\
+ \\
+ \\
+ \\
+ \\
+\end{array}$ & $\begin{array}{l}+ \\
+ \\
+ \\
+ \\
+ \\
+\end{array}$ & $\begin{array}{l}+ \\
+ \\
+ \\
+ \\
+\end{array}$ & & & & & & & & & & & & \\
\hline
\end{tabular}


Продовження табл. 3

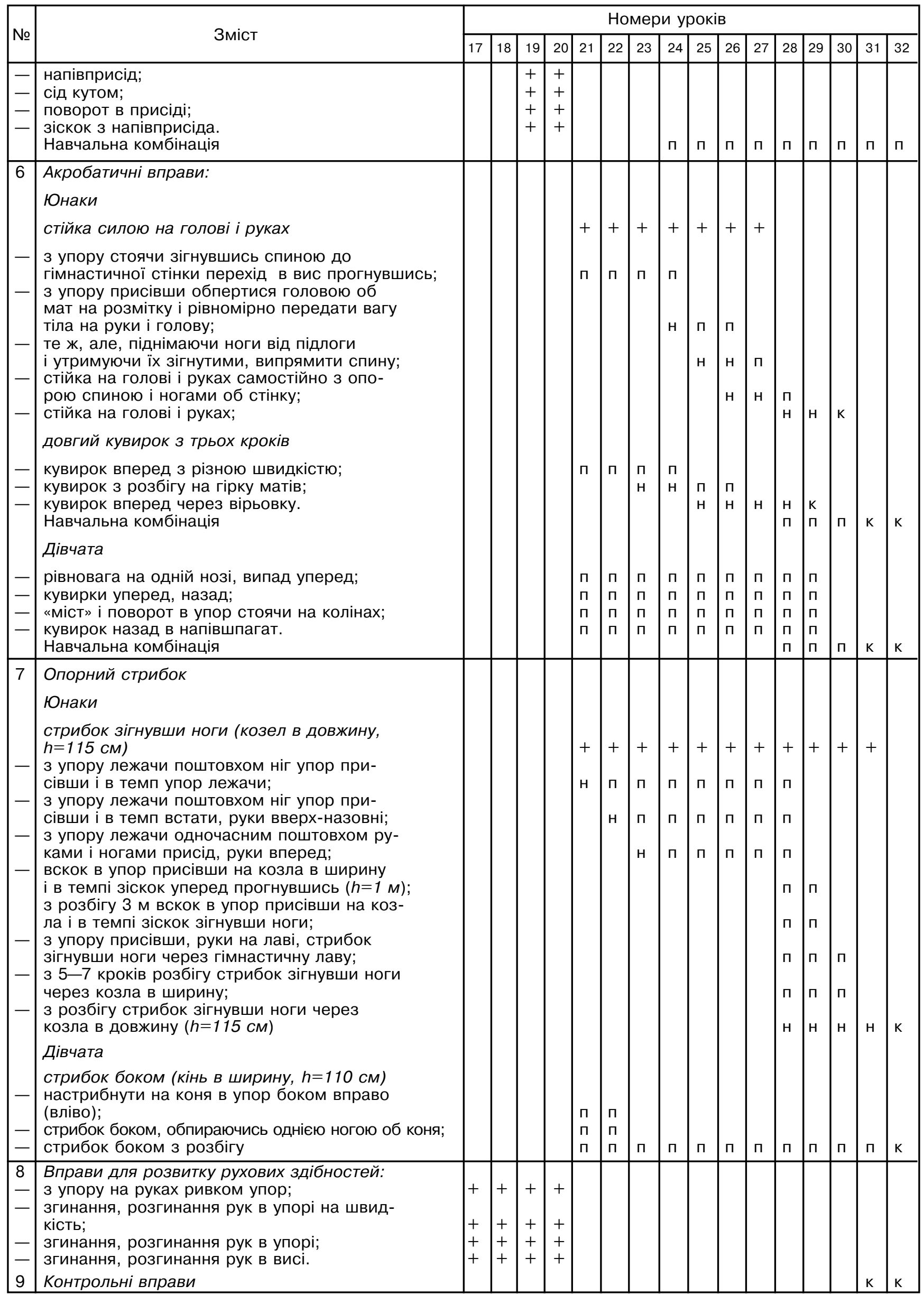


4. Рухлива гра записується в формі ігрової картки і додається до конспекту уроку.

Заключна частина уроку.

В заключній частині уроку записують вправи, сприятливі заспокоєнню організму учнів.

\section{Ефективність методики}

Для перевірки ефективності методики в класі «А» проводилися заняття за вищевикладеним графіком, в класі «Б» - комбіновані уроки.
Результати аналізу показали, що рухову підготовку учнів класу «А» до експерименту і після експерименту можна класифікувати як два різних якісних стани. Подібних змін стану учнів класу «Б» не відбулося.

Таким чином, використання на протязі другої чверті сітьового графіка планування позитивно впливає на динаміку відносної і статичної сили, а також ефективність навчання. Стан рухової підготовки до і після використання силових навантажень класифікується як два різних стани.

Таблиця 4

Порівняння результатів тестування в учнів «А» $\mathrm{i}$ «Б» класу до експерименту

\begin{tabular}{|c|c|c|c|c|c|c|c|c|}
\hline \multirow{2}{*}{ № } & \multirow{2}{*}{ Назва тестів } & \multicolumn{2}{|c|}{ «A» } & \multicolumn{3}{|c|}{ «Б» } & \multicolumn{2}{|c|}{$T$-критерій } \\
\hline & & $M$ & $s$ & $M$ & & $s$ & $T$ & $p$ \\
\hline 1 & $\begin{array}{l}\text { Згинання і розгинання } \\
\text { рук в упорі лежачи, раз }\end{array}$ & 34,83 & $\pm 10,17$ & 44,33 & \pm & 8,50 & 3,08 & $p<0,05$ \\
\hline 2 & Підтягування, раз & 17,50 & $\pm \quad 7,12$ & 21,33 & \pm & 5,01 & 1,16 & $p>0,05$ \\
\hline 3 & Вис на зігнутих руках, с & 46,67 & $\pm 22,29$ & 48,33 & \pm & 18,62 & 0,02 & $p>0,05$ \\
\hline 4 & $\begin{array}{l}\text { Піднімання з сіду } \\
\text { за } 1 \text { хв., раз }\end{array}$ & 51,33 & $\pm \quad 7,94$ & 51,17 & \pm & 4,79 & 0,00 & $p>0,05$ \\
\hline 5 & Стрибок в довжину, м & 2,14 & $\pm \quad 0,20$ & 2,17 & \pm & 0,22 & 0,08 & $p>0,05$ \\
\hline 6 & Кут в упорі, с & 23,00 & $\pm 10,49$ & 18,00 & \pm & 4,47 & 1,15 & $p>0,05$ \\
\hline
\end{tabular}

Таблиця 5

Порівняння результатів тестування в учнів «А» $\mathrm{i}$ «Б» класу після експерименту

\begin{tabular}{|c|c|c|c|c|c|c|c|c|}
\hline \multirow{2}{*}{ № } & \multirow{2}{*}{ Назва тестів } & \multicolumn{2}{|c|}{ «A» } & \multicolumn{3}{|c|}{ «Б» } & \multicolumn{2}{|c|}{ T-критерій } \\
\hline & & $M$ & $s$ & $M$ & & $s$ & $T$ & $p$ \\
\hline 1 & $\begin{array}{l}\text { Згинання і розгинання } \\
\text { рук в упорі лежачи, раз }\end{array}$ & 42,33 & 9,05 & 43,17 & \pm & 9,62 & 0,02 & $p>0,05$ \\
\hline 2 & Підтягування, раз & 21,83 & $\pm 6,74$ & 20,50 & \pm & 5,47 & 0,14 & $p>0,05$ \\
\hline 3 & Вис на зігнутих руках, с & 63,00 & $\pm 25,30$ & 45,00 & \pm & 16,12 & 2,16 & $p<0,05$ \\
\hline 4 & $\begin{array}{l}\text { Піднімання з сіду } \\
\text { за } 1 \text { хв., раз }\end{array}$ & 54,00 & $\pm 6,60$ & 49,00 & \pm & 5,44 & 2,05 & $p<0,05$ \\
\hline 5 & Стрибок в довжину, м & 2,21 & $\pm 0,16$ & 2,17 & \pm & 0,17 & 0,19 & $p>0,05$ \\
\hline 6 & Кут в упорі, с & 30,17 & $\pm 13,36$ & 17,67 & \pm & 5,01 & 4,60 & $p<0,05$ \\
\hline 7 & $\begin{array}{l}\text { Підйом махом вперед, } \\
\text { бали }\end{array}$ & 8,8 & 0,4 & 7,8 & \pm & 0,6 & 6,5 & $p<0,01$ \\
\hline 8 & $\begin{array}{l}\text { Стійка силою } \\
\text { на голові і руках }\end{array}$ & 8,6 & 0,3 & 8,2 & \pm & 0,7 & 9,0 & $p<0,01$ \\
\hline
\end{tabular}

Результати дослідження проаналізовані 3 допомогою методів математичної статистики. Результати тестування представлені в таблицях 4,5 .

Перед експериментом юнаки класів «A» $\mathrm{i}$ «Б» мало чим відрізнялися один від одного. Юнаки контрольної групи показували кращі результати в «згинанні і розгинанні рук в упорі лежачи» $(\mathrm{p}<0,05)$, «підтягуванні», за останніми тестами різниця несуттєва (таблиця 2). Після двох тижнів занять юнаки класу «А» зрівнялися в «згинанні і розгинанні рук в упорі» і показали кращі результати, ніж юнаки групи «Б» в таких тестах, як: 3. Вис на зігнутих руках; 4. Піднімання в сід за 1 хв.; 6. Кут в упорі.

Для визначення зміни стану учнів 9-х класів після силових навантажень та ефективності навчання використовувалася статистика Хотеллінга.

\section{Висновки:}

1. Використання сітьового графіка планування навчальної роботи в 9-х класах позитивно впливає на ефективність навчання і розвиток рухових здібностей.

2. Застосування уроків силової спрямованості на протязі двох тижнів позитивно впливає на динаміку відносної і статичної сили в учнів 9-х класів.

3. Результати аналізу показали, що рухову підготовку учнів 9-х класу «А» до експерименту і після експерименту можна класифікувати як два різних якісних стани. Подібних змін в фізичній підготовці учнів 9-го класу «Б» не відбулося $(\mathrm{p}<0,05)$. 